\title{
The Impact of Stock Market Returns on Foreign Portfolio Investment in Nigeria
}

\author{
Dr. OZURUMBA BENEDICT ANAYOCHUKWU \\ Lecturer, Department of Management Technology \\ Federal University of Technology, P.M.B. 1526, Owerri, Imo State, Nigeria.
}

\begin{abstract}
This research work was designed to investigate the impact of stock market returns on foreign portfolio investment in Nigerian. The objectives of the research are: to identify the relationship between foreign portfolio investment and stock market return, inflation rate and stock market returns and to determine the direction of causality between foreign portfolio investment and stock market returns in Nigeria. The data were collected from Central Bank of Nigeria (CBN) statistical bulletin. The data were consequentially analyzed using E-views statistical package. The methodology used was multiple linear regression analysis to capture the impact of foreign portfolio investment and inflation rate on stock market returns, as well as Granger causality tests to determine the direction of causality between the variables. The results showed that foreign portfolio investment has a positive and significant impact on stock market returns while inflation rate has positive but insignificant impact on stock market returns. In the case of causality test, evidence of the result showed that there is a unidirectional causality running from stock market returns to foreign portfolio investment in the economy, which in turn will foster stock market returns in Nigeria. We therefore recommend that policies that will attract foreign portfolio investment should be pursued in order to enhance stock market returns.
\end{abstract}

Keywords: Capital market, Economic Growth, Inflation, Interest rate, All Share Index, Market Capitalization, Equity, Nigerian Stock Exchange.

\section{Introduction}

Nigeria in the last few years had clamored for foreign portfolio investment in the country. This is believed to be a facilitator of economic growth and development, which leads to industrialization of the economy in the long run (Adeleke et al, 2004). Foreign portfolio investment means the purchase of shares in a foreign country where the investing party does not seek control over the investment. A portfolio investment typically takes the form of the purchase of equity (preference share) or government debt in a foreign stock market, or loans made to a foreign company. Obviously the purchase of bonds issued by a company, which gives no voting rights, or of government debt, and making loans to foreign company do not give control (Bosodersten et al, 1996).

Portfolio investment is a recent phenomenon in Nigeria. Up to the mid 1980's, Nigeria did not record any figure on portfolio investment (inflow or outflow) in her balance of payment account. The nil return on the inflow column of the account is attributable to the absence of foreign portfolio investors in the Nigerian economy. This is largely because of the non-internalization of the country's money and capital markets as well as the non-disclosure of information on the portfolio investments in foreign capital/money markets (Obadan, 2004).

Following a careful review of the consequences of the Exchange Control Act of 1962 on the economy, after some thirty three years of its operation, Nigerian authorities came to the conclusion that the Act had not brought the economy any substantial benefits. The Act was judged inimical to a market driven economy, new policy government had pursued since 1986, with the deregulation of the economy. While equity investment trickled into Nigeria as a result of the Exchange Control Act of 1962, Portfolio Investments dried up, because portfolio investments required an investment climate, which guarantees speedy "free entry" and "free exit" of investment funds into and out of a country in a flash. The investment climate in Nigeria engineered by the Exchange Control Act of 1962 did not guarantee the speedy mobility of funds across international borders. It took the authorities more than three decades to realize that protection of the economy in a world striving to dismantle economic frontiers had not paid off, and that the capital market being a major player in the mobilization of funds for investment has to be liberalized and modernized to enable it capture enough resources for the economy from within and from outside. The Exchange Control Act of 1962 was identified as a major constraint on the growth of the Nigerian capital market. Accordingly the Act was blown away with gale force in 1995, by the strong wind of deregulation, which swept across the Nigerian Macro-economic policy arena, from the beginning of the last quarter of 1986 (Onoh, 2002).

The deregulation of securities pricing by SEC in 1993; the abolition in 1995 of both the Exchange Control Act of 1962 and the Nigerian Enterprises Promotion Decree (NEPD) of 1989, demanded the 
reorganization of the Nigerian Stock Exchange to make it more dynamic and mobile in the provision of adequate liquidity of investment bring up the operation of the exchange to international standard and attract foreign portfolio investors. Accordingly, Federal Government of Nigeria in March 1996 set up a panel on the Nigerian Stock Exchange and, the panel's term of reference include the reorganization of the Nigeria Stock Exchange to make it more dynamic, to recommend ways for modernizing the exchange to bring it up to international standard and to make other recommendations, which in the view of the panel, would strengthen the operation of the exchange, and position it to deal with the domestic and international capital market challenges to the coming millennium (Onoh, 2002).

Nigeria's stock market index is the Nigerian stock exchange's All-share Index (NSE-ASI, or simply ASI), and currently provides a composite picture of the financial health of 233 listed equities. Starting with an index value of 100 in 1984, with increased listings and financial activity, the index value saw changes from 12,$137 ; 20,129 ; 23,845 ; 24,086$; to 33,358 at the end of the years 2002-2006 respectively; with respective endof-year market capitalizations of N0.748 trillion, N1.32 trillion, N1.93 trillion, N2.90 trillion and N5.12 trillion. The ASI attained a value of 57,990 (and N10.180 trillion capitalization) at the end of year 2007, started the year 2008 at 58,580 (with a market capitalization of N10.284 trillion), and then went on to achieve its highest value ever of 66,371 on March 5, 2008 with a market capitalization of about N12.640 trillion.

However, ever since that high, the ASI has severally declined, exhibiting a secular bear posture since July 17, 2008 when, at ASI of 52,910, the Index fell below $20 \%$ of its all time high. It fell further, crossing below the 50,000 mark on August 8, 2008 and closing on October 22 at 42,207 (a 36.4\% loss from the high within just seven months, and a year to date decline of 27.9\%) (Mobolaji, 2008). Meanwhile CBN annual report on Foreign portfolio investment from 2000-2006 are 51,0791.1; 26,317.1; 24, 789.2; 23,555.5; 23,541.0; 375, $858.9 ; 117,218.9$ respectively, imply fluctuation on Foreign portfolio investment in Nigeria (CBN Annual Report, 2006). The figures and dates above suggest an overlap of distress periods. Bearing in mind that there is virtually no cross-ownership of banks (investment or otherwise) between Nigeria and foreign countries, and there is hardly any vibrant domestic mortgage market for there to be sub-prime problems as found particularly in the UK and the USA. It is difficult to pronounce any direct impact. Nevertheless a factor on which this situation may have direct or indirect effect is:

- Foreign portfolio investment withdrawals and withholding in order to service financial problems at home, as well as prospects of reduced foreign direct investment (FDI), are bound to affect investors' confidence and the economic health of Nigeria. (Mobolaji, 2008).

- There has also been competition among emerging markets to attract foreign portfolio investments, which has led to a situation in which in order to sustain inflows of portfolio investments, it has become increasingly important for developing countries to ensure attractive returns for portfolio investors. Often this means offering increasing operational flexibility (Parthapratim, 2006).

On the other hand, several related studies on Nigerian emerging market had neglected the fact that foreign portfolio investment may exert positive influence on stock market returns. Among these papers are the case of Temitope and Osita (2002), Tokunbo (2004), Rose and Sara (1998), examined the trend towards promoting stock market and economic growth but fail to consider the fact that foreign portfolio investment according to Adeleke (2004) is believed to facilitate economic growth and development which leads to industrialization of the economy. Ologunde et al (2006) showed that interest rate exert positive influence with stock market returns, this is in line with the empirical result of Temitope and Osita (2002). Robert (2008) and Shehu (2009) investigated the relationship that exists between stock market returns and the exchange rate. Meanwhile, Adabag (2005) had opined that foreign investors are blamed for financial instability through sudden flows in emerging markets. To this end, it needs to be investigated whether the inflow and outflow of foreign portfolio investments on the stock market is significant enough to lead to an increase or fall in stock market returns.

\section{Scope and Objectives}

The broad objective of this study is to investigate the impact of foreign portfolio investment on stock market returns. Specifically, the study shall:

- Examine the impact of foreign portfolio investment on stock market returns in Nigeria.

- Examine the direction of causality between foreign portfolio investment and stock market returns.

- Examine the impact of inflation on stock market returns.

This study covers a period of twenty years, ranging from 1990-2009. The data are sourced from Central Bank of Nigeria (CBN). It is limited to Market capitalization, Volume of shares traded, Number of listed dealers and all shares Index amongst others. 


\section{Literature Review}

The impact of the Nigeria stock exchange in the economy will be broadly traced into how it helped the capital market in the privatization and commercialization exercise. Privatization is any process or measure which reduces government involvement in a company's economic activity in other words it could be defined as the transfer of state assets to the private sector Commercialization is defined as the re-organization of enterprises wholly or partly owned by the federal government in which commercialization enterprise shall operate as profit making commercial ventures with any intervention from the federal government (Anyanwu 1993).

Stock exchange actually helped the stock market in privatization because apart from handing the efficiency of all the affected companies and reducing their dependency on government, privatization has deepened the stock market to accommodate foreign investors and thereby enables the country to take full advantages of opening of the market (CBN Bullion 1999). The Nigeria stock exchange have been promoting a wide spread ownership of quoted companies, apart from promoting wide speed ownership of share, the stock market also helps in the socio-economic integration of all area of the country hence we have efficient utilization of the nations scares resources, by the stock market and facilitate the development of the economy.

Tobin (1967) in his famous article "liquidity preference as behavior towards risk" formulated the risk aversion theory of liquidity preference based on portfolio selection. This theory removes two major defects of the Keynesian theory of liquidity preference. One Keynes's liquidity preference function depend on the inelasticity of expectation of future interest rate; and two, individuals hold either money or bonds. Tobin's has removed the two defects. His theory does not depend on elasticity of expectation of future interest rate but precedes on the assumption that expected value of capital gain or loss from holding interest bearing aspects is always seen. Moreover, it explains that an individual's portfolio hold money and bonds rather than one at a time.

Tobin started his portfolio selection model of liquidity preference with this presumption that an individual's assets holder has a portfolio of money and bonds. Money neither brings any return nor imposes any risk on him. But bonds yield interest and also bring income. However, income from bonds is uncertain because it involves a risks, capital gains or losses. The greater the investment in bonds, the greater the risk of capital from them. An investor can bear the risk if he is compensated by an adequate return from bonds (Jhingan, 2002).

Defenders of capital flow liberalization argue that foreign portfolio investment tends to increase the liquidity and the efficiency to local markets. They claim that in the long -run, the expected return decreases as a result of market integration. Henry (2000), Bekaert and Harvery (2000) and Kim and Singal (2000) address this issue and the abnormal after market liberalization. These studies argue that, with more foreign investor, startup companies as well as existing companies can raise capital easier. The entrance of foreign investors also increases the liquidity of local market, and makes the base of investors broader, increasing the risk sharing.

Another issue is the effect of the volatility after the entrance of foreign investors in the market. Although stock returns increase immediately after market opening, there is no volatility increase. On the contrary, in the long-run volatility decreases as reported by Kim and Sigal (2000) and Bekaert and Harvey (1997). Stock market also brome more efficient, as Kim and Singal (2000) and Tabak (2003) through a test of random walk hypothesis.

Another benefit is that foreign investors demand better rules and regulation from the local markets. These rules primarily concern the information quality and quantity. Better disclosure and higher accounting standard are part of regulations (Evans 2002). Hence, financial markets become more transparent by the participation of foreigners, leading to better allocation of resources and healthier financial markets.

Unfortunately, liberalization of local markets for foreign investors does not bring only benefits. Unlike foreign direct investment foreign, portfolio investors ask for faster returns of their investment. And this may lead these investors to suddenly enter or leave a country. Therefore, many countries are worried about the destructive effect of foreign equity outflow during a crisis. For instance, some countries imposed rules to prevent the outflow (Kim and Singal, 2000), consistent with these rules, Stiglitz (1998) argued that in developing countries, there is more need for capital flow controls since these countries are more vulnerable to changes in international flows.

In a local market, the expected return is a product of the local beta and the local market risk premium. On the other hand, in the case of a segmented market with foreign investors, the return is the product of the world market beta the world risk premium (Bekaert and Harvey 2002). Therefore, in segmented market, it is expected to have lower return. This is concurrent within the equity market segmented theory of Stulz (1995) which suggest that changes in the investor base of emerging market equities will increase risk sharing and liquidity. Therefore expected return fall and prices rise.

Based on the market segmentation theories there are two main factors that can explain the increase in share prices when there is an increase foreign participation. Firstly, by increasing the investors' base, diversification and risk sharing will increase (Merton, 1987). Secondly the liquidity risk may be lowered by the 
flow new investors. Merton's market segmentation model shows that the equity prices may rise as a result of wider investor base for a given stock. This model can be applied to the emerging market case to illustrate how the prices will be affected when the investor base is broadened by the inclusion of foreign investors. Clark and Berko (1996) use this model to assess the impact of foreign portfolio investment in Mexico. To start this model, Merton differentiates between a segmented market in which there are some restrictions and a fully segmented case where there are no restriction. Hence, he states that in the former case, the expected returns would be higher than in the later case due to diversification and risk sharing, as seen before. Based on Merton's model, Clark and Benko (1996) test the broadening base hypothesis using Mexican data.

They use a regression model with a constant and one intercept.

$\mathrm{R}_{\mathrm{t}}=\mathrm{B}_{\mathrm{o}}+\mathrm{B}_{1}$ NFP. $1_{\mathrm{t}}+\mathrm{E}_{\mathrm{t}}-\mathrm{-}_{\mathrm{-}}$

Where $\mathrm{R}_{\mathrm{t}}$ is the return and NFPI is the net foreign portfolio inflow as a percentage of the market capitalization, both at time t.

The broadening base hypothesis would be rejected if $\mathrm{B}_{1}$ were equal to zero. In fact this analysis cannot rely only on this coefficient test. If the percentage of foreign investor holding were not increasing one time, there would be no base broadening, therefore even if the coefficient B1 is significantly positive, the hypothesis could not be supported.

Clark and Berko (1996) show graphically that the percentage of foreign investor holding in Mexico has increased during the period analyzed. However, a more format statistical test would be necessary to assure that the base is really broadening.

Following this line of reasoning, Tabak (2003) tested for co-integration of Brazilian stock returns and foreign exchange portfolio investment (FEPI) on the Sao Paulo stock exchange (Bovespa). He found that the Bovespa index is co-integrated of order one with the FEPI. Then he built an error correction model, being the FEPI series integrated of order one during the period analyzed.

One important methodological issue when analyzing the above hypothesis is whether to use exogenous or control variables in the specification or regression. One natural specification would be a VAR (Vector autoregressive) model with returns and not foreign portfolio flows as endogenous variables. Chen (2002) use a VAR model with these two variables and no control variables. Clark and Berko (1996) also use control variables when assessing the base broadening hypothesis.

Dahlquist and Roberston (2004) use only the excess return on the world market as exogenous variable. Clark and Berko (1996) use several control variables. Including movements in foreign stock markets, the level and control variables including movements in foreign stock markets, the level and change in Short-term Mexico interest rates, the percentage change in Peso dollar exchange rate the within the month volatility of Mexican stock prices, shifting assessment of Mexican country risks and a measure of revision to aggregate the earnings forecasts for Mexican stock. Adeleke (2004) used the Augmented Dickey fuller (ADF) unit root test to check the stationary of exchange rate and other relevant variables. Robert (2008) investigated the time series relationship between stock market returns and the macroeconomic variables of exchange rate and oil price in for emerging economies: Brazil, Russia, India and China (BRIC) using the Box-Jerkins Azuma model.

\section{Methodology}

In order to achieve to the study objective, two different methodologies shall be adopted.

We shall apply a single linear equation model for our first and third objectives. We will represent a compact functional form of our model as follows

$\begin{array}{lll}\mathrm{R} & =\mathrm{f}(\mathrm{FPI}, \mathrm{EXR}, \mathrm{INF}, \mathrm{INT}) \text {----- } \\ \text { Where } & & \\ \text { FPI } & \text { foreign portfolio investment } \\ \mathrm{EXR} & = & \text { real exchange rate } \\ \mathrm{INT} & = & \text { real interest rate } \\ \mathrm{INF} & = & \text { inflation rate }\end{array}$

Transforming equation 1 into a linear function:

$\mathrm{R}_{\mathrm{t}} \quad=\quad \alpha_{0}+\alpha_{1} \mathrm{INT}_{\mathrm{t}}+\alpha_{2} \mathrm{INF}_{\mathrm{t}}+\alpha_{3} \mathrm{FPI}_{\mathrm{t}}+\alpha_{4} \mathrm{EXR}_{\mathrm{t}}+\mu$

Where $\alpha_{0}=$ constant or intercept

$\mu=$ stochastic term

Introducing lag operator and ECM we have:

$\mathrm{Rt}=\alpha_{0}+\alpha 1 \mathrm{R}_{\mathrm{t}-1}+\alpha_{2} \mathrm{INF}_{\mathrm{t}}+\alpha_{3} \mathrm{INT}_{\mathrm{t}-1}+\alpha_{4} \mathrm{INF}_{\mathrm{t}}+\alpha_{5} \mathrm{INF}_{\mathrm{t}-1}+\alpha_{6} \mathrm{FPI}_{\mathrm{t}}+\alpha_{7} \mathrm{FPI}_{\mathrm{t}-1}+\alpha_{8} \mathrm{EXR}_{\mathrm{t}}+\alpha_{9} \mathrm{EXR}_{\mathrm{t}-1}+\alpha_{10} \mathrm{ECM}_{\mathrm{t}-1}+$

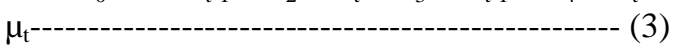

Equation 3 is the error correction model with four contemporaneous values. (ie. $\alpha_{1}, \alpha_{4}, \alpha_{3}, \alpha_{6}, \alpha_{8}$ ).

One general hypothesis that can be tested is whether there is Granger causality between returns in Naira of the

Nigeria stock Exchange- ASI (hereafter Returns) and the foreign portfolio investment inflow. We start with the 
following VAR model to test for Granger causality. This model is in line Dahlquist and Robertson (2004) as well as Adabag et al (2005). This model shall be used to capture objective two.

$$
\begin{aligned}
& R_{t}=C_{1}+\sum_{i=1}^{n} \alpha i R_{t-1} \sum_{i=1}^{n} \beta F P_{I t}-1+\ell_{1 t}--------------(4) \\
& F P I_{t}=C_{2}+\sum_{i=1}^{n} \delta F P I_{t-1}+\sum_{i=1}^{n} \gamma i R_{t}-1+\ell_{2 t}-------------(5)
\end{aligned}
$$

A Wald $-\mathrm{F}$ test shall be used to test the following hypothesis.

$\mathrm{H}_{01}$ : FPI does not Granger cause Return

$\mathrm{H}_{02}$ : Return does not Granger cause FPI.

There is possibility of the following outcomes from the Granger causality test.

1. Unidirectional causality from R to FPI is indicated if the estimated coefficients on the lagged R in equation

(1) are statistically different from zero as a group (i.e, $\left(\sum \alpha i \neq 0\right)$ and the set of estimated coefficients on the lagged FPI in equation (2) is not statistically different from zero $\left(\sum \alpha i=0\right)$.

2. Conversely unidirectional causality from FPI to R exists if the set of lagged R coefficients in equation (1) is not statistically different from zero (i.e, $\Sigma \alpha \mathrm{i}=0$ ) and the set of the lagged FPI coefficients in equation (2) is statistically different from zero (i.e. $\Sigma \alpha 1 \neq 0$ ).

3. Feedback, or bilateral causality is suggested when the sets of R and FPI coefficients are statistically significantly different from zero in both regression.

4. Finally, independence is suggested when the set of R and FPI coefficient are not statistically significant in both the regression ( Gujarati, 2004).

\subsection{Model Justification}

The choice of VAR model is necessary to determine the direction of causality between returns and foreign portfolio investment. The OLS is necessary because the relationship between the independent and the dependent variables will be most efficiently represented by the ECM if cointegration is established between them. Very often the dependence variables respond to the explanatory with a lapse of time (Gujarati, 2004). The use of this model will also avoid spurious regression.

\subsection{Estimation Procedure}

The time series properties of the data will be examined using ordinary least square (OLS) technique. The statistical test of parameter estimates will be conducted using their standard error, $\mathrm{t}$-test, $\mathrm{f}$-test, $\mathrm{R}^{2}$ and Durbin Watson (DW) statistic. Specifically the DW statistic shall be employed for auto correlation test. The economic criteria will show whether the coefficients of the variables conform to economic a priori expectation, while the statistical criteria test will be used to assess the significance of the overall regression.

\subsection{Unit Root Test}

Dickey and Fuller looked at the distribution of this king of test statistic and found that OLS estimates are biased down (towards stationary) and OLS standard errors. Thus, it is possible that many series that you would have thought were stationary based on OLS regression were in fact generated by random walks (Cochrane, 2005) we shall therefore subject all the variables to unit root test using the Augmented Dickey Fuller (ADF) test specified in Gujarati (2004) as follows.

$$
\Delta Y_{t}=\beta_{1}+\beta_{2}+\delta Y_{t-1}+\alpha i \sum_{i=1}^{m} \Delta Y_{t-1}+\varepsilon_{t}---------------(6)
$$

Where $\Delta \mathrm{Y}_{\mathrm{t}}=$ change in time $\mathrm{t}$

$\Delta \mathrm{Y}_{\mathrm{t}-1}=$ the lagged value of the dependent variables

$\Sigma_{\mathrm{t}}=$ white noise error term.

If in the above $\delta=0$, then we conclude that there is a unit root. Otherwise there is not unit root, meaning that it is stationary. The choice of lag will be determined by Akaike information criteria.

\subsection{Co-integration and Error Correction Mechanism}

Pre-test of the variables' order of integration in equation (5) will shows their order of integration. If any of the explanatory variable(s) have the same order of integration with the dependent variable we may suspect cointegration between the variable in question. Then we estimate their linear combination at their level form without constant term and save the residual. However, if the residual is stationary after subjecting if to units root test, then our suspicion holds. This will necessitate the introduction of the error correction 
mechanism, hence correction model (ECM). The ECM will determine the speed of adjustment to equilibrium. However, supposing after testing for cointegration and we discovered that there is no cointegration among the variable, it implies that we shall rely on the model in equation (2) as our ultimate model.

\subsection{Unit Roots Test Result}

\section{Model Estimation and Results}

In this study, the Augmented Dickey Fuller (ADF) unit roots tests was employed to test for the time series properties of model variables. The null hypothesis is that the variable under investigation has a unit root against the alternative. The decision rule is to reject the null hypothesis if the ADF statistic value exceeds the critical value at a chosen level of significance (in absolute term). These results are presented in table I below.

Table 4.1: Unit Roots Test Result

\begin{tabular}{|l|l|ll|l|ll|}
\hline Variable & \multicolumn{3}{|l}{ ADF statistics } & ADF statistics \\
\hline & Level & Critical values & $\mathbf{1}^{\text {st }}$ difference & \multicolumn{2}{l|}{ Critical values } \\
\hline FPI & -1.8013 & $1 \%$ & -3.8575 & -3.726919 & $1 \%$ & -3.8877 \\
& & $5 \%$ & -3.040 & & $5 \%$ & -3.0521 \\
& & $10 \%$ & -2.6608 & & $10 \%$ & -2.6672 \\
\hline R & -1.44187 & $1 \%$ & -3.8575 & -4.821866 & $1 \%$ & -3.8877 \\
& & $5 \%$ & -3.040 & & $5 \%$ & -3.0521 \\
& & $10 \%$ & -2.6608 & & $10 \%$ & -2.6672 \\
\hline INT & -1.44959 & $1 \%$ & -3.8575 & -5.199391 & $1 \%$ & -3.8877 \\
& & $5 \%$ & -3.040 & & $5 \%$ & -3.0521 \\
& & $10 \%$ & -2.6608 & & $10 \%$ & -2.6672 \\
\hline EXR & -0.66082 & $1 \%$ & -3.8575 & -3.830322 & $1 \%$ & -3.8877 \\
& & $5 \%$ & -3.040 & & $5 \%$ & -3.0521 \\
& & $10 \%$ & -2.6608 & & $10 \%$ & -2.6672 \\
\hline INF & 2.26714 & $1 \%$ & -3.8575 & -3.05474 & $1 \%$ & -3.8575 \\
& & $5 \%$ & -3.040 & & $5 \%$ & -3.040 \\
& & $10 \%$ & -2.6608 & & $10 \%$ & -2.6608 \\
\hline
\end{tabular}

Source: Computer Analysis using E-views

The results of table 1 above show that all the variables are non-stationary in level form since their ADF values are less than the critical values at $5 \%$ and $10 \%$, the null hypothesis of no unit root was accepted for all the variables but was rejected in $1^{\text {st }}$ difference. Thus, we conclude that the variables under investigation are integrated of order one. (i.e. I(1)). Since the variable are integrated of the same order. We therefore, examine their co-integrating relationship using Johansen co-integration procedure.

\subsection{Co-integration Test Result}

A necessary but not sufficient condition for co-integrating test is that each of the variables be integrated of the same order. The Johansen co-integration test uses two statistics test namely: the trace test and the likelihood eigenvalue test. The first row in each of the table test the hypotheses of no co-integrating relation, the second row test the hypothesis of one co-integrating relation and so on, against the alternative of full rank of co-integration. The results are presented in table 2 below.

Table 4.2: Co-integrating Test Result between the Variables: FPI, R,EXR, INT, INF

\begin{tabular}{|l|l|l|l|l|}
\hline Eigen value & Likelihood Ratio & $\begin{array}{l}5 \% \\
\text { value }\end{array}$ & $\begin{array}{l}1 \% \text { critical critical } \\
\text { value }\end{array}$ & $\begin{array}{l}\text { Hypothesized } \\
\text { No of CE(s) }\end{array}$ \\
\hline 0.935219 & 100.4527 & 68.52 & 76.07 & None** \\
\hline 0.761030 & 51.19116 & 47.21 & 54.46 & At most $1^{*}$ \\
\hline 0.628551 & 25.42565 & 29.68 & 35.65 & At most 2 \\
\hline 0.343301 & 7.59490 & 15.41 & 20.04 & At most 3 \\
\hline 0.001683 & 0.029964 & 3.76 & 6.65 & At most 4 \\
\hline
\end{tabular}

Source: Computer Analysis using E-views

$*(* *)$ denotes rejection of the hypothesis at $5 \%(1 \%)$ significance level.

L.R. test indicates 2 co-integrating equation(s) at $5 \%$ level of significance

\subsubsection{Interpretation of Co-integrating Results}


From Table 4.2 above, the likelihood statistics indicates the presence of two co-integrating equation at $5 \%$ significance level which implies that stock market return proxied by all share index $(\mathrm{R})$ and foreign portfolio investment (FPI) are co-integrated. This shows that there is a positive long-run relationship between stock market returns and foreign portfolio investment in Nigeria.

Table 4.3: Multiple Regression Results: Dependent variable: $\mathbf{R}$

\begin{tabular}{|c|c|c|c|c|}
\hline Variables & Coefficient & $\begin{array}{l}\text { Standard } \\
\text { errors }\end{array}$ & $\begin{array}{l}\mathrm{t}- \\
\text { statistics }\end{array}$ & Probability \\
\hline Constant & 9.717435 & 2.281433 & 4.259355 & $0.0001 * *$ \\
\hline Log FPI & 0.174021 & 0.062051 & 2.690430 & $0.0145 * *$ \\
\hline $\begin{array}{l}\text { Log } \\
\text { EXR }\end{array}$ & 0.771119 & 0.198844 & 3.878001 & $0.0015^{* *}$ \\
\hline Log INF & -0.003091 & 0.108003 & $\begin{array}{l}- \\
0.028616\end{array}$ & 0.9775 \\
\hline Log INT & $\begin{array}{l}- \\
1.834857\end{array}$ & 0.673000 & $\begin{array}{l}- \\
2.726380\end{array}$ & $0.0156 * *$ \\
\hline $\mathrm{R}^{2}$ & 0.875924 & & & \\
\hline $\begin{array}{l}\text { Adjusted } \\
\mathrm{R}^{2}\end{array}$ & 0.842838 & & & \\
\hline $\begin{array}{l}\text { Durbin } \\
\text { Watson }\end{array}$ & 1.157325 & & & \\
\hline $\begin{array}{l}\mathrm{F} \\
\text { statistics }\end{array}$ & 26.47351 & & & \\
\hline 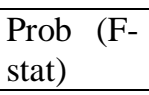 & $0.00001 * *$ & & & \\
\hline ECM & -0.357 & & & \\
\hline
\end{tabular}

Source: Computer Analysis using E-views

\section{** denotes variable is significant at $1 \%$ significance level}

\subsubsection{Interpretation of Regression Results}

From table 4 above, we can state the estimated equation as: $\mathrm{R}_{\mathrm{t}}=9.717+0.174$ FPI+0.771 EXR-0.003 INF -1.834 INT-

From equation (1) as in table 3 , the regression result shows that foreign portfolio investment has a positive significant impact on stock market returns in Nigeria. This conforms to the a priori economic theory which postulates that increase in foreign portfolio investment will lead to increase in stock market returns. The coefficient of 0.174 suggests that a $1 \%$ increase in foreign portfolio investment will to increase in stock market returns by $17.4 \%$.

Exchange rate has a positive and significant impact on stock market returns in Nigeria. This is also in line with the economic theory. Increase in exchange rate which implies depreciation in domestic currency relative to foreign currency will lead to increase in export which in turn will lead to firms' sales and profit and hence increase in stock market returns. Specifically, $1 \%$ depreciation in exchange rate will lead to about $77.1 \%$ increase in stock market returns. This validates the flow oriented model by Dornbusch and Fisher (1980) of exchange rate determination which postulates that depreciation of exchange rate will affect international competitiveness and balance of trade positions, and consequently, the real output of the country, which in turn affects the current and future expected cash flows of the firms and their stock prices.

Inflation rate has a negative but insignificant impact on stock market returns. This is in line with theory postulates suggesting that high rate of inflation increases the cost of living and a shift of resources from investments to consumption. This leads to a fall in demand for market instruments and subsequently leads to a reduction in the volume of stock traded and stock market returns.

Interest rate has negative and significant impact on stock market returns. This is also in line with a priori expectation. An increase in interest rate will increase the opportunity cost of holding money and investors will substitute holding interest bearing securities for share hence falling stock market returns (Adam and Tweneboah 2008; Craigwell et al, 2009).

Interestingly, the overall regression is highly significant at $1 \%$ level of significance. This suggests that the joint effects of all the included variables are significant. The value of coefficient of determination and adjusted coefficient of determination are 0.876 and 0.843 respectively. These suggest that the model is highly 
fitted. Specifically, the coefficients suggest that about $87.6 \%$ of the variation in stock market returns is explained by variation in the explanatory variables (foreign portfolio investment, exchange rate, inflation rate and interest rate). The remaining $12.4 \%$ is explained by the error term.

Durbin Watson statistic shows that there is negative autocorrelation in the model.

The Error Correction Model (ECM) measures the speed at which any disequilibrium in the model is adjusted to equilibrium. From our result, the ECM is -0.357 and meets the a priori expectation suggesting that about $35.7 \%$ of the disequilibrium in the model will be corrected every year. The implication is that it will take about 2 years and ten months for any disequilibrium will be adjusted back equilibrium.

Following objective two, the direction of causality between foreign portfolio investment and stock market returns were tested using Granger causality test. The results are presented in Table 4.4 below. The null hypothesis of no direction of causality was tested against the alternative that there exists a direction of causality between the variables.

In this case, there are four possibilities namely:

1. Unidirectional causality from foreign portfolio investment (FPI) to stock market returns (R) when the coefficient of FPI is statistically significant.

2. Unidirectional causality from stock market returns (R) to foreign portfolio investment (FPI) when the coefficient of $\mathrm{R}$ is statistically significant.

3. Feedback or bidirectional causality when the sets of R and FPI coefficients are statistically significant.

4. Finally, mutual independence, when FPI and R coefficient are statistically insignificant.

Table 4.4: Granger Causality Test Results

\begin{tabular}{|l|l|l|l|}
\hline Null hypothesis & F-statistical & P-value & Conclusion \\
\hline FPI does not granger cause R & 0.14754 & 0.86425 & Do not reject Ho \\
R does not granger cause FPI & 4.48703 & 0.03298 & Reject Ho \\
\hline
\end{tabular}

Source: Computer Analysis using E-views

\subsection{Interpretation of Pair-wise Granger Causality Test Result}

From table 4 above, the causality test reveals that stock market returns (R) proxied by ASI Granger cause foreign portfolio investment in Nigeria. This indicates that there is a robust positive unidirectional causality from stock market returns to foreign portfolio investment in Nigeria. The implication is that an increase in stock market returns will attract foreign portfolio investment since hot money will always move to where return on investment is high relatively. This supports the endogenous growth theory on perfect capital mobility. The conclusion was arrived based on the fact that the F-statistics was statistically significant at $5 \%$ as indicated by their p- values. This result corroborates the findings of Odionye (2011).

\subsection{Descriptive Statistics}

The characteristics of the distribution are presented in table 1 below

Table 4.5: Descriptive Analysis Result.

\begin{tabular}{|l|l|l|l|l|l|}
\hline & $\mathrm{R}$ & FPI & EXR & INT & INF \\
\hline Skewness & 1.499918 & 0.910675 & -0.090849 & 0.822766 & 1.478200 \\
\hline Kurtosis & 4.011345 & 2.884560 & 1.174382 & 3.958705 & 3.979079 \\
\hline Jarque-Bera & 2.870440 & 2.115534 & 2.804913 & 3.022410 & 8.02412 \\
\hline Probability & 0.254360 & 0.249632 & 0.245992 & 0.220644 & 0.01756 \\
\hline
\end{tabular}

Source: Computer Analysis using E-views

Kurtosis is a measure of the peakedness and flatness of the distribution of the series. From the table above, stock market returns, inflation rate and interest rate are leptokurtic relative to its normal distribution since their kurtosis values are greater than 3 . However, foreign portfolio investment is mesorkurtic implying that the series has a normal peak while exchange rate is platykurtic suggesting that its distribution is flat relative to normal distribution.

Skewness which is a measure of the shape of the distribution shows that exchange rate has a long tail to the left while those of stock market returns, foreign portfolio investment, inflation rate and interest rate suggest a long tail to the right since their values are greater than 1 .

Jarque-Bera is a statistical test that determines whether the series is normally distributed. This statistic measures the difference of the skewness and the kurtosis of the series with those from the normal distribution. The null hypothesis is that the series is normally distributed against alternative that it is not. Clearly, the JarqueBera statistic rejects the null hypothsis of no normal distribution for inflation rate only. However, the null hypothesis of no normal distribution is accepted for stock market returns, foreign portfolio investment, 
exchange rate and interest rate since their probability values are greater than 0.05 . Thus, we conclude that except inflation rate, all other variables in the model are not normally distributed.

\section{Conclusion}

The ADF results show that the series are non stationary in their level form, therefore random walk series and are integrated of order one.

Johansen co-integration test result shows evidence of co-integration implying that there is a long run relationship between stock market returns and foreign portfolio investment in Nigeria.

Result from ECM suggests that about $35.7 \%$ of the disequilibrium will be corrected every year.

$>$ There is significant positive impact of foreign portfolio investment on stock market returns in Nigeria.

Exchange rate has positive and significant impact on stock market returns in Nigeria.

Inflation rate has negative but insignificant impact on stock market returns.

Interest rate has negative and significant impact on stock market returns.

The pair-wise Granger causality test shows that there is a strong unidirectional causality running from stock market returns to foreign portfolio investment in Nigeria.

\subsection{Recommendations}

Based on the research findings, the following recommendations aimed are made.

$>$ Since foreign portfolio investment has positive and significant on stock market returns in Nigeria, policies that will attract foreign portfolio investment should be pursued in order to enhance stock market returns.

$>$ Economic reforms must target macroeconomic stability, removal of structural distortions and creation of business-friendly environment to enhance domestic production capacity. Anti- inflationary policy like non- expansionary monetary and fiscal policies as well as inflation-adjusted interest rate policy should be pursued to attract foreign portfolio investors and discourage capital flight in the country.

$>$ Strengthening of supervisory and regulatory bodies in the financial system.

\section{References}

[1]. Adabag, M.C. and Ornelas, J.R.J. (2005); Behavior and Effects of foreign Investors I Istanbul Stock Exchange.

[2]. Adeleke S.O. (2004): Impact of Exchange Rate on Foreign private investment in Nigeria.

[3]. Anyanwu, J.C. (1993): "Monetary Economics; Theory, policy and Institutions". Hybrid

[4]. Publishers ltd, Onitsha, Nigeria.

[5]. Bekaert, G and Harvey, C.R. (2002): Research in Emerging Market Finance: "looking to the future working paper, September 11".

[6]. Bekaert, G and Hervey, C.R. (2000) Foreign Speculators and Emerging Equity Markets "Journal of Finance 55, P. 565 -613.

[7]. Bekaert, Greet, and Havrevy, C.R. (1997) Emerging equity Market Volatility, "Journal of Financial Economics 43, p. 29-77".

[8]. Bosodersten and Geogrey Reed (1996): International Economic, Third editions: Macmillan press Ltd.

[9]. CBN (2006) Central Bank of Nigeria Statistical Bulletin, Abuja, CBN

[10]. CBN(1999) Central Bank of Nigeria Statistical Bullion, Abuja, CBN

[11]. Chen, Y. (2002) Domestic Investors Herding Behaviour in Reaction to Foreign Trading "202 National Taiwan University International Conference in finance"

[12]. Clark J. and Berko, E. (1996): Foreign Investment Fluctuations and Emerging market Stock returns: "The case of Mexico research paper from Federal research Banks of New York November 1996, Number 1935"

[13]. Cochrane, J.H. (2005): Time series for macroeconomic and finance; University of Chicago 5807 S. Woodlawn.

[14]. Dahlguist, M. and Robrtson, G. (2004): A note on foreign trading and price effects across firms; “ Journal of Banking and Finance 28, p 615-632".

[15]. Evans, K. (2002) Attracting Foreign Direct Investment for Development. "Global Forum on international investment (December)".

[16]. Gujarati, D. N. (2004): Basic Economics, Fourth Edition: Tata McGraw-Hill Publishing Company Ltd, New Delhi.

[17]. Henry P.B. (2000) Stock Market Liberalization Economics Reform, and Emerging Market Equity Prices "Journal of Finance 55, P. 529-564".

[18]. Jhingan M.L. (2002): Macro Economic Theory: Tenth Revised and Enlarge Edition, New Delhi, Vinda Publication LTD.

[19]. Kim, E.H and Singal, V. (2000) Stock Market Openings: Experiences of Emerging Economies, "Journal of Business 73, p. 25-66".

[20]. Merton, R.C. (1997): A simple model of capital market equilibrium with incomplete information: "Journal of Finance 42 , P. 483 510 ".

[21]. Mobolaji E.A. (2008) The Global Financial Meltdown: “impact of Nigeria's capital Market and foreign reserves".

[22]. Obadan M.I. (2004): Foreign Capital flow and External Debt perspectives on Nigeria and the LDCS Groups, Ibadan University Printer, Nigeria.

[23]. Odionye, J.C. (2011): An Empirical Analysis of the Relationship between Exchange Rate and Stock Prices in Nigeria. "Unpublished M.Sc Thesis, University of Nigeria, Nsukka.

[24]. Olugunde A.O., Elumilade D.O, Asaolu T.O. (2006) Stock Market capitalization and interest Rate in Nigeria: A time series analysis. "International Research Journal of Finance and Economics ISSN 1450-2887 Issues a (2006)

[25]. Onoh, J.K (2002): Dynamics of money, Banking and Finance in Nigeria. An emerging market: Astra Meridian publishing, Lagos.

[26]. Parthapratim P. (2006): Foreign portfolio investment Stock market and economic development: A case study of India: "Draft paper submitted for the Annual conference of Development and Change mission promoting development in a globalized world".

[27]. Robert D. Gay. Jr. (2008) Effect of Macroeconomic variables on stock market returns for four emerging economies: Brazil, Russia, India, and China. "International Business and Economics Research Journal-March 2008, volume 7, Number 3".

[28]. Shehu U. R. A(2009) Stock prices and exchange rate interaction in Nigeria: an intra Global financial Crisis Maiden investment. "Social science research Network.

[29]. Stiglitz, J. (1998): Boats, Planes and Capital Flows. "Financial Times, March 25". 
[30]. Stulz, R.M. (1995): International Portfolio choice and assts pricing: "An integrative survey, in Jarrow et al eds. Handbooks in operations Research and Management Science: Finance (North-Holland)" .

[31]. Tabak, B.M. (2003) The Random Walk Hypothesis and the Behavior of Foreign Capital Portfolio flows"'the Brazilian stock Market Case, Applied financial Economic 13".

[32]. Temitope, W. (2002) Financial liberalization, emerging stock markets and Economic development in Africa "An international Development Research Centre Documents.

[33]. Tokumbo (2004) Does stock market promote Economic Growth in Nigeria. "Journal of Applies Finance, IJAF 2004".

[34]. Tobin, J(1967) "Liquidity Preference as a Behaviour Towards Risk" R.E.S. volume 25 Adopted from Mankiw G.N (1997) and Jhingan (2000). 